\title{
Uma breve história das representações do corpo feminino na sociedade
}

\section{O corpo feminino em debate.}

MATOS, Maria Izilda S. de; SOIHET, Rachel (Orgs.).

São Paulo: Ed. da UNESP, 2003. 222 p.

A obra $O$ corpo feminino em debate busca desnaturalizar a experiência feminina, colocando-a sob o foco do seu aspecto relacional. Os seus textos reunidos abordam a problemática do corpo marcada em alguns períodos da história e perpassada por diversas perspectivas. É apresentada a construção do corpo como produto de historicidade (contextualizado principalmente na França e no Brasil nos séculos XIX e XX), tendo representações nas artes e nos discursos médico, jurídico, políticofilosófico, religioso e jornalístico. Em toda a história fica evidente a divisão entre o 'público', no que tange aos papéis masculinos, e do 'privado', quanto aos papéis femininos. Michelle Perrot contrapõe esse 'privado' ao silêncio do corpo feminino, que se configura no silêncio das práticas abortivas, do abuso sexual, do incesto e da violência doméstica.

Entre os espaços sociais em que se apresenta, nas artes o corpo feminino é reconhecido como objeto do olhar e do desejo (aspectos que logo se tornam alvo das campanhas publicitárias), mas aparece calado devido ao pudor que the é exigido como marca de feminilidade. De acordo com Perrot, esse silêncio permeia a função anônima e impessoal da reprodução, bem como a reprovação do prazer sexual, que através dessas práticas sociais constitui a 'frigidez' feminina. Esse silêncio oprimente é reforçado pelo discurso médico no que se refere às doenças das mulheres (sempre consideradas eternas doentes) e ao seu restrito papel familiar. O tratado médico renascentista $D e$ universo mulierum medicina, de Rodrigo de Castro, mesmo concebendo, segundo Lígia Bellini, de uma maneira mais positiva os atributos peculiares ao sexo feminino, continuava a reproduzir uma justificativa natural para sua arbitrária inserção ao âmbito doméstico e sua incompatibilidade com a vida pública.

Entre 1890 e 1930, conforme aponta Maria Izilda Matos, com o desenvolvimento da urbanização e a expansão da ação da medicina na capital paulista, os médicos sanitaristas se colocaram no direito de disciplinar a sociedade, ordenando a sexualidade e os prazeres. Às mulheres ficaria o cuidado com a saúde e o bemestar da família, condenando-se o trabalho extradoméstico e as práticas abortivas. Os médicos destacavam a conexão entre o útero e o sistema nervoso central, de modo que as atividades intelectuais femininas poderiam gerar crianças doentes e mal-formadas. Assim, aos homens se reservava a esfera pública, ficando sob sua responsabilidade o desenvolvimento da civilização urbana, através de sua agressividade e inteligência. Aqui temos a ciência e a política representadas pela medicina, que, como produtora de uma 'verdade' acerca dos papéis masculinos e femininos, está embasada em questões organicistas, delimitando, a partir desse saber, os melhores rumos para a sociedade.

Em alguns momentos da história, de acordo com Agnès Fine, o saber médico se confunde com a sabedoria popular, como entre 1920 e 1950 , quando as mulheres foram acusadas de envenenarem seus filhos com seu leite 'estragado', tendo como explicação fatores que se fundavam principalmente na lógica do sistema antigo de representações dos humores femininos, como, por exemplo, o fato de estarem menstruadas durante a amamentação, sentirem libido, irritação, cansaço, etc. 
Os discursos políticos legitimavam o controle dos casamentos e da natalidade, ainda antes do século XVIII. Segundo Jean-Louis Fournel, em 1637 Campanella publica sua Philosofia realis, obra em que pressupõe o corpo feminino como responsável pela conservação da espécie e do bom governo, e ao mesmo tempo o reduz ao status do instrumento de procriação, lançando-o ao silêncio do 'privado'. E nesse mesmo 'silêncio' recorria-se à prática do aborto e do infanticídio, devido a problemas econômicos que impossibilitavam criar um bebê, ou para manter a honra em tal sociedade moralista. Assim, muitas vezes as mulheres encontravam a própria morte, ou eram cruelmente condenadas, servindo de exemplo a todas que pensassem em fazer o mesmo. Uma pesquisa realizada por Joana Maria Pedro em textos de livros, jornais e revistas no início do século $X X$, em Santa Catarina, relata o que ocorria com as mulheres que cometiam, ou estavam envolvidas com infanticídio e aborto.

Essa coação física se estende historicamente com a política natalista da França no século XX, narrada por Françoise Thébaud: o declínio demográfico, acompanhado do temor da degenerescência da 'raça francesa', faz surgir o movimento natalista intitulado Aliança Nacional pelo Crescimento da População Francesa, quando as mulheres passam a exercer o dever da maternidade e os casais são coagidos a terem mais filhos. Esses episódios deixam de ocorrer definitivamente apenas nos anos $1970 \mathrm{com}$ o movimento feminista, que reivindica os direitos civis e políticos para as mulheres, estabelecendo a 'greve de ventres'.

Também no sentido político, a divisão das tarefas domésticas entre homens e mulheres ainda é uma luta. Na França, a lei de 2 de novembro de 1892 restringiu a jornada de trabalho para as mulheres a 10 horas, além de Ihes proibir o trabalho noturno. Para Régine Dhoquois, o principal motivo para isso foi permitir que 0 trabalho pudesse ser conciliado com a educação dos filhos, o que garantiria a conservação da saúde da raça, para que a França pudesse contar com um exército saudável.

Quanto ao aspecto mítico, conforme apontado por Pauline Schmitt-Pantel, até mesmo a idéia da "criação da mulher" a traz como introdutora da morte e do mal no mundo, o que pode ser visto nos relatos de criação de Pandora, na tradição grega, e de Eva, na judaico-cristã. E talvez por ser a mulher sempre considerada a 'pecadora' da história, é que foram imputados tantos pudores na educação sexual das moças, principalmente no século XVIII, quando lhes era negado o direito de obter conhecimentos acerca de sua sexualidade antes do casamento, mais precisamente a experiência do coito. Por causa desse tabu, a primeira relação sexual era vivenciada com culpa e vergonha. De acordo com Gabrielle Houbre, na década de 1820 a condessa Claire de Remusat publica um ensaio sobre a educação das mulheres, o que possibilitou a prática do flerte antes do casamento, mas foi apenas em 1930 que a idéia de educação sexual realmente adquire espaço. Ainda acerca da sexualidade, na virada do século XX no Brasil, segundo Rachel Soihet, com o surgimento do carnaval, as mulheres atreveram-se a exibir seus corpos e a participar de danças sensuais (o que já era praticado no século XIX pelas mulheres negras nas festas populares do Rio de Janeiro), um dos fatos que virou símbolo de emancipação feminina.

A partir desses diferentes aspectos lançados na obra acerca do corpo feminino como produto histórico, vê-se o quanto as questões que envolvem o 'público' e o 'privado' estão presentes. As explicações dadas para que se justifique essa divisão de papéis, em alguns casos, a apresentam como natural e universal. Aquilo que é tornado possível como experiência feminina deve conviver com a arbitrariedade do silêncio, em que determinadas práticas e saberes são absolutamente lançados para fora do espaço reservado às mulheres, enquanto outras são designadas aos homens. As mesmas relações de poder que imprimem essas marcações acerca dos papéis sexuais dirigem-se principalmente à manutenção da ordem e do funcionamento social.

A medicina apareceu como alicerce idelológico à cristalização dessas relações de poder, contribuindo para que as principais decisões políticas obtivessem sucesso ancoradas nas diferenças entre homens e mulheres, e oferecendo a estas um espaço social delimitado, restrito, utilitarista. Em outra palavras, o papel da medicina foi o de produzir uma 'ortopedia' quanto ao masculino e ao feminino, colaborando na reprodução e manutenção dos aspectos positivistas-funcionalistas que a ordenação social exigia em determinados contextos e épocas.

Vemos também o quanto as questões acerca da sexualidade permeiam as relações de gênero, em que as mulheres precisam lutar pela aproximação a essa temática, rompendo com moralidades, participando de movimentos expressivos (os carnavais do Rio de Janeiro no século XIX, por exemplo), lutando por uma 
educação abrangente e libertária. Mesmo que o tema da sexualidade feminina apareça calado e restrito na história, é através dos primeiros ruídos corajosamente produzidos que se configuram as nuances de sua emancipação.

Com o advento do movimento feminista e as audaciosas conquistas históricas, as mulheres foram obtendo seu merecido espaço na vida pública e mais direitos sobre seu próprio corpo, colaborando assim para a desconstrução de alguns discursos produzidos e mantidos pela ideologia masculina. Contudo, ainda na contemporaneidade, tem-se muito para conquistar, e é preciso não perder de vista os aspectos e contextos em que a mulher ainda é discriminada, tendo como resultado dessas práticas salários desiguais em comparação aos dos homens, dupla jornada de trabalho (devido à falta de uma cultura para a divisão de tarefas domésticas) e pequena ocupação de cargos. As conquistas foram inúmeras e de incomensurável valor, mas a luta ainda se faz persistir.

Daniela Angeli Universidade Federal de Santa Catarina 